\section{How much of the missing heritability of ALS is hidden in known ALS genes?}

\author{
Philip Van Damme ${ }^{1,2,3}$
}

\section{Further research of rare variants in ALS genes is needed to guide diagnosis and counseling of patients}

Over the last decade, our knowledge about the heritability of Amyotrophic Lateral Sclerosis (ALS) has greatly improved. More than 25 genes have been associated with ALS. ${ }^{1}$ Some gene mutations segregate with high penetrance in people with familial ALS, some genetic variants have a lower penetrance or merely act as ALS risk alleles. With all of these genes roughly $40 \%-80 \%$ of familial ALS, but also $5 \%-15 \%$ of sporadic ALS can be explained. Indeed, in patients with sporadic ALS, a genetic component is also present: the estimated heritability of sporadic ALS is about 60\%. ${ }^{2}$ This suggests that the genetic architecture of ALS is complex and consists of a mixture of gene mutations that differ in noxiousness and in frequency. At the same time, it is clear that there is considerable missing heritability. With the advent of next generation sequencing technology, more and more rare genetic variants are being identified in known ALS genes and it is often challenging to classify such variants as pathogenic or benign.

In the JNNP paper by Müller $e t a l^{3}$, the results of a comprehensive analysis of known ALs genes in a cohort of 301 German ALS families are presented. In about half of these, a pathogenic mutation could be identified, mostly in the genes C9orf72, SOD1, FUS, TARDBP or TBK1. This suggests that these are the top genes that should be offered in the diagnostic setting in central Europe. In addition, several previously unreported variants were found in known ALS genes. On the basis of stringent criteria, the authors classified these as pathogenic, likely pathogenic or as variants of unknown significance.

Correspondence to Dr Philip Van Damme, Department of Neurology, University Hospitals Leuven, Leuven 3000, Belgium; philip.vandamme@uzleuven.be
Other recent studies in ALS populations from the UK and the Netherlands also identified an increased burden of rare variants in known ALS genes, in the coding regions and in the untranslated regions. ${ }^{4-6}$ Interestingly, there are also patients with combinations of rare variants in known ALS genes. This suggests that ALS can be caused by a single highly penetrant mutation or a combination of a few less penetrant rare variants. Hence, ALS appears to have an oligogenic origin.

Further research is needed to establish the exact level of pathogenicity at the single variant level of all genetic variation in ALS genes and to establish if combinations of rare variants can cause ALS. A global whole genome sequencing project, aiming to sequence 15000 patients with ALS and 7500 controls under the banner of Project MinE (http://www.projectmine.com) will help to answer some of these questions and to uncover missing heritability within known ALS genes.

Detailed information about the risk of each variant is also crucial with regard to the counselling of patients and their families. Straightforward counselling is only possible for established pathogenic mutations. The complexity of counselling will only continue to increase, as more patients with combinations of rare variants will be seen, due to the increased use of next generation sequencing technologies in a diagnostic setting.

Funding The author holds a senior clinical investigatorship of FWO-Vlaanderen and is supported by grants from Opening the Future Fund (KU Leuven), the Fund for Scientific Research Flanders (FWOFlanders), the Interuniversity Attraction Poles (IUAP) program P7/16 of the Belgian Federal Science Policy Office, the ALS liga Belgium, the Alzheimer Research Foundation(SAO-FRA), the Flemish Government initiated Flanders Impulse Program on Network s for Dementia Research (VIND), Flanders Innovation \& Enterpreneurship (IWT grants Project MinE and
iPSCAF), the Latran Foundation, the European Research Council under the European Union Joint ProgrammeNeurodegenerative Disease Research(JPND) project STRENGTHand RiMod-FTD , the European E-Rare-2 project PYRAMID

Competing interests None declared. Patient consent Not required.

Provenance and peer review Commissioned; internally peer reviewed.

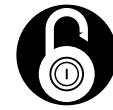

\section{OPEN ACCESS}

Open access This is an open access article distributed in accordance with the Creative Commons Attribution Non Commercial (CC BY-NC 4.0) license, which permits others to distribute, remix, adapt, build upon this work non-commercially, and license their derivative works on different terms, provided the original work is properly cited and the use is non-commercial. See: http:// creativecommons.org/licenses/by-nc/4.0/

(C) Article author(s) (or their employer(s) unless otherwise stated in the text of the article) 2018. All rights reserved. No commercial use is permitted unless otherwise expressly granted.

\section{Check for updates}

To cite Van Damme P. J Neurol Neurosurg Psychiatry 2018;89:794.

Received 14 March 2018

Revised 25 January 2018

Accepted 26 March 2018

Published Online First 12 April 2018

\section{Sinked}

- http://dx.doi.org/10.1136/jnnp-2017-317611

J Neurol Neurosurg Psychiatry 2018;89:794.

doi:10.1136/jnnp-2018-318354

\section{REFERENCES}

1 Hardiman O, Al-Chalabi A, Chio A, et al. Amyotrophic lateral sclerosis. Nat Rev Dis Primers 2017;3:17085.

2 Al-Chalabi A, Fang F, Hanby MF, et al. An estimate of amyotrophic lateral sclerosis heritability using twin data. J Neurol Neurosurg Psychiatry 2010;81:1324-6.

3 Müller K, Brenner D, Weydt P, et al. German ALS network MND-NET. Comprehensive analysis of the mutation spectrum in 301 German ALS families. J Neurol Neurosurg Psychiatry 2018;89:817-27.

4 van Blitterswijk M, van Es MA, Hennekam EA, et al. Evidence for an oligogenic basis of amyotrophic lateral sclerosis. Hum Mol Genet 2012:21:3776-84.

5 Morgan S, Shatunov A, Sproviero W, et al. A comprehensive analysis of rare genetic variation in amyotrophic lateral sclerosis in the UK. Brain 2017:140:1611-8.

6 Cooper-Knock J, Robins H, Niedermoser I, et al. Targeted genetic screen in amyotrophic lateral sclerosis reveals novel genetic variants with synergistic effect on clinical phenotype. Front Mol Neurosci 2017;10:370 